\title{
Phenotypic diversity in lima bean landraces cultivated in Brazil, using the Ward-MLM strategy
}

\author{
Raimundo Nonato Oliveira Silva ${ }^{1 *}$, Marīlia Lobo Burle ${ }^{2}$, Juliano Gomes Pádua ${ }^{2}$, \\ Ângela Celis de Almeida Lopes ${ }^{3}$, Regina Lucia Ferreira Gomes ${ }^{3}$, \\ and Jaime Martinez-Castillo ${ }^{4}$
}

\section{ABSTRACT}

Lima bean (Phaseolus lunatus L.) is an important source of protein for people as it contributes all of the essential amino acids necessary for humans. In Brazil, lima bean has a great relevance, mainly in the Northeast, where it is an alternative income in addition to a food source. It has a high degree of phenotypic variation for seed traits, which are important for understanding the genetic diversity and origin of this crop. We aimed to characterize 166 accessions of cultivated lima bean from Brazil using qualitative and quantitative descriptors through the WardMLM (Modified Location Model) in order to analize the organization of the genetic diversity and the origin of this germplasm. High genetic variability was detected and seed length and width characteristics were the main contributors to genetic divergence among the accessions. Results showed the presence of accessions with characteristics typical of the Mesoamerican and Andean gene pools, and another group with intermediate characteristics of these two gene pools. Our results will be useful to breeding programs, since currently there is little information on the genetic diversity and the origin of the lima bean landraces cultivated in Brazil.

Key words: Breeding, germplasm characterization, joint analysis, morphological markers, Phaseolus lunatus.

${ }^{1}$ Universidade Federal do Piauí, Campus Universitário Amílcar Ferreira Sobral, BR 343, km 3,5. Meladão 64800000, Floriano, Piauí, Brasil. "Correponding author (jraio@ufpi.edu.br).

${ }^{2}$ Empresa Brasileira de Pesquisa Agropecuária, Embrapa Recursos Genéticos e Biotecnologia, Parque Estação Biológica - PqEB - Av. W5 Norte (final), 70770-900, Brasilia, DF, Brasil.

${ }^{3}$ Universidade Federal do Piauí, Campus Universitário Ministro Petrônio Portela, Ininga, 64049-550, Teresina, Piaú, Brasil.

${ }^{4}$ Centro de Investigación Científica de Yucatán, Calle 43 No. 130, C.P. 97200, Colonia Chuburná de Hidalgo, Mérida, Yucatán, México.

Received: 28 August 2016.

Accepted: 31 December 2016.

doi:10.4067/S0718-58392017000100004.

\section{INTRODUCTION}

Lima bean (Phaseolus lunatus L.) is composed of two botanical varieties: var. silvester for the wild material and var. lunatus for the domesticated one (Baudet, 1977). Studies have indicated the existence of three major gene pools: One Andean gene pool (A) and two Mesoamerican gene pools (MI and MII); with one domestication event in each of them: 1) for A, the midaltitude western valleys between Ecuador and Peru in South America (Maquet et al., 1997); 2) the central eastern region from Mexico for MI (Serrano-Serrano et al., 2012; AnduezaNoh et al., 2013); and 3) the region located between Guatemala and Costa Rica for MII (Andueza-Noh et al., 2013; 2015). Recent evidence from microsatellite markers have suggested another possible domestication event in South America (Jaime MartínezCastillo, personal communication), but lack of wild lima bean collections from South America limits explore this hipotesis. Within the var. lunatus, Baudet (1977) indicated the existence of three cultigroups: 1) Sieva, with medium-sized and flat seeds; 2) Potato, with small globular seeds; and 3) Big lima, with large flat seeds. Big Lima represents the A gene pool, while Sieva and Potato represent the MI and MII gene pools. Lima bean has a high level of polymorphism, mainly related to seed traits (Lioi, 1994). This aspect was firstly used to recognize the main gene pools and later to characterize the genetic diversity of this species (Santos et al., 2010).

As a crop, lima bean is the second most important legume of the genus Phaseolus on the world (Maquet et al., 1999). It is an important source of protein for rural populations in South America and Africa (Lioi et al., 1998). In Brazil, lima bean is known as fava, favabelém or feijão-de-lima, and it has considerable importance in the Northeast of Brazil, where it is used as a food and an alternative income source for the local population (Santos et al., 2008; Silva et al., 2015). Collections obtained from Brazil have show that the genetic diversity, reflected in the number of landraces and morphological variation of seed, could be as high as that reported in the Yucatan Peninsula, a region considered as a center of diversity for the Mesoamerican gene pool (MartínezCastillo et al., 2008; 2012; 2014). Our objectives were to test the organization of the genetic diversity present in lima bean accessions from Brazil through the Ward-MLM procedure using morphological and phenological characters and to explore the origin of this germplasm. 


\section{MATERIALS AND METHODS}

A total of 166 lima bean accessions were used in this study. The 157 accessions provided by Germplasm Bank of Embrapa Genetic Resources and Biotechnology, collected in different localities from five main regions from Brazil, and nine accessions obtained from the International Center for Tropical Agriculture (CIAT, Cali, Colombia). The experiment was conducted in a greenhouse located in Brasilia-DF, with two replicates of the accessions sown in pots in a completely randomized design. Four seeds were sown per pot, which were reduced to one plant after thinning and held upright with a bamboo stake. Insect and disease control was performed when necessary.

Eight quantitative descriptors and eight qualitative traits were evaluated as recommended by Biodiversity International (International Board for Plant Genetic Resources, Rome, Italy; IBPGR, 1982). The eight quantitative variables used were: 1) number of days from emergence to flowering (Flo, d) - number of days from first emergence to the stage where $50 \%$ of the plot was in flowering; 2) pod length (PL, mm) - 10 mature pods at random were measured (in the case of curved pods, we measured the longest straight line to the base of the tip pod); 3) pod width (PW, mm) - measured including the maximum width of 10 mature pods at random; 4) number of locules per pod (NLP) - number of locules in 10 randomly sampled pods; 4) number of seeds per pod (NSP) - average number of seeds per pod, measured randomly in 10 mature pods; 5) seed length (SL, mm) - mean length of 10 randomly selected seeds; 6) seed width ( $\mathrm{SW}, \mathrm{mm})$ - the mean width of 10 random seeds; 7) thickness of the seed (TS, mm) the mean thickness of 10 random seeds; and 8) weight of 100 seeds (W100S, g). The eight qualitative variables used were: seed shape (SS), seed profile (SP), seed color (SC), pattern seed color (PSC), second pattern seed color (SSC), pattern of the seed tegument (PST), pod curvature (CP), and growth habit $(\mathrm{GH})$. The measures $(\mathrm{mm})$ were determined using a digital caliper. The significance of the quantitative variables was analyzed by $\mathrm{F}$ test at 5\% probability.

At present, multivariate analysis permit to handle and interpreted a big number of characters simultaneously. This type of approach is important for the classification of genotypes conserved in genebanks, especially with the recent advances in computer technology (Ortiz et al., 2008; Gonçalves et al., 2009). Multivariate analyses usually consider qualitative or quantitative characteristics separately, although the joint analysis of quantitative and qualitative variables is a potentially more complete indicator of variability in germplasm banks. Gonçalves et al. (2008) showed that limited use of methods using both quantitative and qualitative variables stems from the lack of knowledge in statistical techniques and free software needed to analyze them jointly. This joint strategy for data analysis is the Ward-MLM procedure proposed by Franco et al. (1998), using Ward's clustering method (Ward Junior, 1963). It defines groups by the Gower dissimilarity algorithm (Gower, 1971), and is an approach that has not been previously used in lima bean. In this study, the quantitative and qualitative variables were analyzed simultaneously, using the WardMLM procedure for the formation of groups through the cluster and IML procedures of the SAS program version 9.0 (SAS Institute, Cary, North Carolina, USA). For the Ward clustering method, the distance matrix was provided by Gower's algorithm (Gower, 1971).

The definition of the ideal number of groups was performed according to the pseudo $\mathrm{F}$ and pseudo $\mathrm{t}^{2}$ criteria that show the differences between groups and correlation of characteristics with canonical variables that were verified by the CANDISC procedure (SAS Institute). Statistical analyzes were performed using the SAS program (version 9.0).

\section{RESULTS AND DISCUSSION}

Significant differences were observed among the different lima bean accessions $(\mathrm{P}<0.01)$ for the means of all traits (Table 1), which implies the existence of genetic variability among the studied accessions. The coefficients of variation (CVs) obtained ranged from 5.49 (pod length) to 9.29 (number of seeds per pod), which was considered low for all the variables, indicating good experimental precision and indicated that characteristics evaluated were little affected by environmental, thus conferring reliability to the obtained results.

Of all accessiones analyzed, $81.93 \%$ of them had an indeterminate climbing growth habit, $12.05 \%$ indeterminate semi-climbing and $6.02 \%$ showed determinate growth

Table 1. Estimates of mean squares obtained in the analysis of variance of the characteristics evaluated for 166 accessions of lima beans from Embrapa Genetic Resources and Biotechnology, Brasilia-DF, 2010.

\begin{tabular}{|c|c|c|c|c|c|c|c|c|c|}
\hline \multicolumn{10}{|c|}{ Mean squares } \\
\hline Source & DF & Flo & PL & PW & NLP & NSP & SL & SW & TS \\
\hline & & $\mathrm{d}$ & $\mathrm{mm}$ & 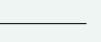 & & & 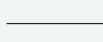 & $\mathrm{mm}$ & 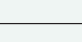 \\
\hline Accessions & 165 & $1474.07^{* *}$ & $435.32^{* *}$ & $14.00^{* *}$ & $0.25^{* *}$ & $0.26^{* *}$ & $15.72^{* *}$ & $5.04^{* *}$ & $0.83^{* *}$ \\
\hline Error & 166 & 63.19 & 12.49 & 1.05 & 0.05 & 0.07 & 1.02 & 0.39 & 0.19 \\
\hline Mean & & 95.87 & 64.30 & 14.46 & 2.79 & 2.76 & 12.38 & 9.15 & 5.55 \\
\hline $\mathrm{CV} \%$ & & 8.29 & 5.49 & 7.10 & 8.41 & 9.29 & 8.17 & 6.79 & 7.86 \\
\hline
\end{tabular}

DF: Degrees of freedom; Flo: number of days from emergence to flowering; PL: pod length; PW: pod width; NLP: number of locules per pod; NSP: number of seeds per pod; SL: seed length; SW: seed width; TS: thickness of the seed; CV: coefficient of variation.

"*ignificant at the 0.01 probability level in the F test. 
habit. The number of days from emergence to flowering ranged between 26 and $153 \mathrm{~d}$, showing a wide variability among the evaluated accessions. Concerning to this trait, 18 accessions showed shorter cycles in comparison with the found in the literature on studies in Brazil. These accessions were: BF7, BF87, BF132, BF133, BF199, BF201, BF202, BF205, BF206, G25137, G25140, G25142, G25143, G25165, G25633, G26200, G26222 and G27059 with 40, $35,48,40,49,37,39,40,41,34,41,31,30,30,30,30,31$ and $26 \mathrm{~d}$, respectively.

Regarding the pod length trait there wide variability exists for that characteristic, ranged between 42.50 and $129.17 \mathrm{~mm}$, with an average of $64.33 \mathrm{~mm}$. The highest average value of pod length was observed in genotype BF113. In lima bean it is an important feature, considering that larger pods contain large seeds, which is preferred among the lima bean consumers. In lima beans, the study of the morphological variation of seeds has been one of the main criteria used to explain their origin and genetic diversity (Vargas et al., 2003). In this study, the characteristics that contributed most to the genetic variability were seed length and width (Table 2). For seed traits, this study showed wide morphological variation, with values from 8.28 to $22.53 \mathrm{~mm}$ and from 6.54 to $14.17 \mathrm{~mm}$ for length and width of seeds, respectively (Table 2). As for seed color (SC), a wide variability was verified: $29.52 \%$ brown, $22.29 \%$ white, $18.07 \%$ cream, $10.84 \%$ red, $7.23 \%$ black, $4.82 \%$ light brown, $4.22 \%$ red-purple, $1.20 \%$ gray and yellow and $0.60 \%$ rose (Table 3 ). The Ward-MLM procedure indicated the existence of three groups according to the pseudo $\mathrm{F}$ and pseudo $\mathrm{t}^{2}$ criteria.

According to Mingoti (2005), the pseudo F and pseudo $\mathrm{t}^{2}$ tests, which determine the ideal number of accessions groups in a cluster analysis, are similar to a hypothesis test in which each clustering step is related to a test to compare mean vectors of the two clusters jointed to form a new group. Nevertheless, focus should be given to larger values of pseudo $\mathrm{F}$ and pseudo $\mathrm{t}^{2}$, since they are related to the least probability of test significance and rejecting the equality of means with major significance. If the equality of mean vectors are rejected, two groups will not be united again in another different group. Gonçalves et al. (2009) indicated that the number of groups can vary according to the species,
Table 3. Variables and number of accessions by group of qualitative characteristics, in each of the three groups (GI, GII, and GIII) formed by the WARD-MLM strategy from the $\mathbf{1 6 6}$ accessions of lima beans from the Embrapa Genetic Resources and Biotechnology, Brasilia-DF, 2010.

\begin{tabular}{|c|c|c|c|}
\hline \multirow[b]{2}{*}{ Variables } & \multicolumn{3}{|c|}{ Group } \\
\hline & GI (74) & GII (51) & GIII (41) \\
\hline \multicolumn{4}{|l|}{ Seed color (SC) } \\
\hline White & 11 & 11 & 15 \\
\hline Gray & - & 2 & - \\
\hline Yellow & - & 2 & - \\
\hline Light Brown & 5 & 3 & - \\
\hline Brown & 25 & 14 & 10 \\
\hline Rose & 1 & - & - \\
\hline Red & 12 & 4 & 2 \\
\hline Red-Purple & 4 & 2 & 1 \\
\hline Black & 1 & 1 & 10 \\
\hline Another & 15 & 12 & 3 \\
\hline \multicolumn{4}{|l|}{ Pattern seed color (PSC) } \\
\hline Absent & 45 & 20 & 22 \\
\hline Light brown or orange & 5 & 6 & 13 \\
\hline Dark Brown & 10 & 12 & 3 \\
\hline Red & 1 & 9 & - \\
\hline Black & 13 & 4 & 3 \\
\hline \multicolumn{4}{|l|}{ Seed shape (SS) } \\
\hline Spherical & 63 & 46 & 20 \\
\hline Elliptical & 10 & 4 & 20 \\
\hline Oblong & 1 & 1 & 1 \\
\hline \multicolumn{4}{|l|}{ Seed profile (SP) } \\
\hline Flat & 42 & 23 & 41 \\
\hline Semi-flat & 26 & 22 & - \\
\hline Full & 6 & 6 & - \\
\hline \multicolumn{4}{|l|}{ Seed size (SZ) } \\
\hline Small & 27 & 31 & - \\
\hline Medium & 46 & 20 & 13 \\
\hline Large & 1 & - & 28 \\
\hline \multicolumn{4}{|l|}{ Growth habit (GH) } \\
\hline Determinate shrubby & 1 & 9 & - \\
\hline Indeterminate semi-climbing & 13 & 2 & 5 \\
\hline Indeterminate climbing & 60 & 40 & 36 \\
\hline
\end{tabular}

number of accessions and number and type of descriptors. However, the same authors noted that more precise criteria for group formation results in less subjective groups.

Group I contained the highest number of accessions (74 accessions). This group comprised the accessions that had higher mean values for the number of days to flowering trait, with small, semi-flattened and spherical seeds, with lowest mean values for length and width of seeds. The characteristics found in this group are similar to those showed by cultivated accessions from the Mesoamerican

Table 2. Values of maximum, minimum, and average for the quantitative characteristics for each of the three groups (GI and GII, GIII) formed by the strategy Ward-MLM and the first canonical variable (CAN1), determined from 166 accessions of lima beans from the Embrapa Genetic Resources and Biotechnology, Brasilia-DF, 2010.

\begin{tabular}{|c|c|c|c|c|c|c|c|c|c|c|}
\hline \multirow[b]{3}{*}{ Characters } & \multicolumn{9}{|c|}{ Group } & \multirow[b]{3}{*}{ CAN1 } \\
\hline & \multicolumn{3}{|c|}{ GI } & \multicolumn{3}{|c|}{ GII } & \multicolumn{3}{|c|}{ GIII } & \\
\hline & Maximum & Minimum & Medium & Maximum & Minimum & Medium & Maximum & Minimum & Medium & \\
\hline Flo, d & 153.00 & 78.00 & 108.01 & 112.00 & 26.00 & 72.02 & 151.00 & 37.00 & 99.90 & -0.130 \\
\hline $\mathrm{PL}, \mathrm{mm}$ & 129.17 & 42.50 & 58.33 & 93.05 & 45.67 & 59.62 & 122.50 & 57.44 & 80.49 & 0.624 \\
\hline $\mathrm{PW}, \mathrm{mm}$ & 21.35 & 8.40 & 13.50 & 20.36 & 9.58 & 13.73 & 27.32 & 10.12 & 16.94 & 0.637 \\
\hline $\mathrm{SL}, \mathrm{mm}$ & 13.56 & 8.28 & 10.89 & 17.95 & 8.58 & 11.47 & 22.53 & 12.98 & 16.94 & 0.912 \\
\hline $\mathrm{SW}, \mathrm{mm}$ & 9.76 & 6.54 & 8.23 & 11.70 & 7.16 & 8.73 & 14.17 & 9.29 & 11.17 & 0.899 \\
\hline W100S, g & 147.03 & 17.52 & 34.25 & 72.00 & 17.89 & 32.83 & 92.45 & 35.79 & 60.68 & 0.431 \\
\hline
\end{tabular}

Flo: Number of days from emergence to flowering; PL: pod length; PW: pod width; SL: seed length; SW: seed width; W100S: weight of 100 seeds. 
gene pool. Group II brought together nearly all accessions $(90 \%)$ of determinate growth habit. Accessions to this type of growth habit in lima bean are more uniform in the number of days to flowering and maturity. Furthermore, although they reach lower production compared with the indeterminate growth habit, they require less care and do not require staking or excessive hand work, which allows for mechanized harvesting. Also, group II comprised accessions with short cycles, as indicated in the early number of days from emergence to flowering. Early genotypes are less susceptible to the action of pests and diseases, they cost less, and they perform well in crop rotation. Until now, there were not reports in the Brazilian germplasm accessions of lima beans with values of less than $60 \mathrm{~d}$. Many accessions evaluated in this study have values less than $60 \mathrm{~d}$, such as BF7, BF87, BF133, BF179, BF203, BF205 and BF206, including all accessions coming from the CIAT. Considering seed characteristics found in this group, it is intermediate to the Mesoamerican and Andean gene pools. Group III was formed by accessions with the highest mean values for the length and width of the seeds, which are all flat (Table 2). This group has accessions whose seeds are mostly classified as large, according to Baudet (1977) and Castiñeiras et al. (1991). Thus, it was observed that accessions belonging to group III were significantly different from the others obtained from the Germplasm Bank of Embrapa lima bean. The characteristics found in this group are similar to those showed by cultivated accessions from the Andean gene pool.

High variability was observed within groups as seen by the range of variation of the characters (Table 2). The first two canonical variables explained $99.0 \%$ of the total variation among groups, obtained by the Ward-MLM methodology (Figure 1), and enabled to visualize the genetic variability among accessions evaluated by graphic dispersion analysis. Cabral el al. (2010), using the same procedure on common bean ( $P$. vulgaris L.), obtained $87.86 \%$ of the total variation and report that high values

Figure 1. Plot of the first two canonical variables (CAN1 and CAN2) of the three groups (G1-G3) formed with the WardMLM strategy, considering 166 lima bean accessions used in the study.

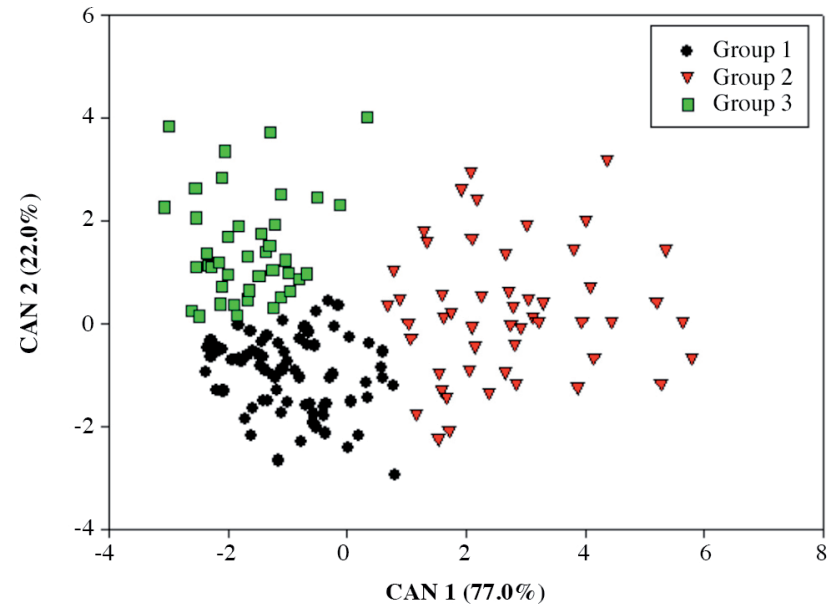

indicates that the graphic representation of the first two canonical variables is adequate to verify the relationship among groups and among accessions inside the same group.

Several studies have shown that the Ward-MLM statistical procedure is a useful technique to detect genetic divergence and to cluster genotypes by simultaneously using morphological and agronomic data. Ortiz et al. (2008) worked with 50 accessions of eight maize (Zea mays L.) races from high altitude regions of Peru using six agronomic descriptors, and concluded that the Ward-MLM procedure soundly classifies the accessions and may be an additional refinement and a complement for the racial classification based on the visual evaluation. Gonçalves et al. (2009) studied 57 accessions of common bean ( $P$. vulgaris) from Brazil using 10 morpho-agronomic traits, they detected high genetic variability, separating the accessions from Andean origin as a different cluster. Sudré et al. (2010) studied genetic diversity of 56 Capsicum spp. accessions using 26 morpho-agronomic descriptors, and observed the separation of the species $C$. annuum, $C$. frutescens, $C$. baccatum and $C$. chinense in different groups.

\section{Implications for the origin of the germplasm}

The genetic diversity present within each group of lima bean landraces found in the present study is greatly important for breeding programs, considering that genetic and breeding studies are still incipient for this crop in Brazil. The WardMLM statistical procedure proved to be a useful technique to detect genetic divergence and to cluster genotypes using data simultaneously from quantitative and qualitative variables. In the present study, group I showed morphological characteristics typical of the Mesoamerican gene pool and group III showed morphological characteristics observed in the Andean gene pool. This result allowed us to infer the existence in Brazil of accessions from the Mesoamerican and Andean domestication centers. Our results also indicated the existence of a group II with intermediate characteristics between both gene pools before mentioned. One possible explanation to the existence of the group II is that Brazil can be acting as a hybrid zone where landraces from the Andean and Mesoamerican gene pools are growing sympatrically. Fofana et al. (1997), using RAPD markers, showed that wild forms and landraces, within each gene pool, are genetically differentiated. However, they suggested that landraces may be more prone to exchange genetic between the two gene pools through cross-hybridizations (the species is predominantly autogamous with variable levels of outcrossing), which would cause an increase in genetic diversity as compared to wild forms. According to these authors, this hypothesis is partly supported by the lower differentiation observed between landraces of the two gene pools than between wild forms.

Another, and perhaps more interesting explanation about the existence of the group II is that Brazil could be a domestication center for the lima bean. Since 
several decades ago, authors suggested the existence of a domestication event en Sud America. Fofana et al. (1997) observed that among mesoamerican wild forms and landraces, the accessions from Costa Rica to Colombia are distinct from those farther north, indicating that a form of domestication in this transition region can be suggested and that this hypothesis could be consistent with the northern Andean center of diversity proposed by Debouck (1986). Also, Lioi et al. (1998) using isozyme diversity and RFLP of the rDNA, and Lioi and Galasso (2002) using digoxigenated synthetic oligonucleotides complementary to simple repetitive DNA sequences, reported the occurrence of intermediate forms representing a genetically distinct group present in the contact zone of the Mesoamerican and Andean gene pools. More recently, Andueza-Noh et al. (2015) analyzing 10 microsatellite loci observed that the Mesoamerican landraces collected in Sud America are not related genetically with the wild populations collected in Mexico and Central America, it suggesting that the Sud American landraces may have been domesticated from Sud American wild populations still not collected. However, to confirm the hypothesis about a domestication event in Sud America is necessary to make further investigation including more accessions (specially wild accessions) and using molecular techniques such as chloroplast and ribosomal DNA sequences (Serrano-Serrano et al., 2012; Andueza-Noh et al., 2013).

Regardless of the hypothesis before mentioned about the existence of group II, the presence in Brazil of landraces from the Mesoamerican and the Andean gene pools could be favoring the presence of high levels of genetic diversity in the lima bean landraces cultivated by the Brazilian farmers (as showed in this study), and Brazil could be an important center of diversity for this important crop, as indicated for the Yucatan Peninsula in Mexico (MartínezCastillo et al., 2008). It is necessary to make studies using molecular markers as microsatellites (SSR) or secuences inter-microsatellites (ISSR) to confirm this hypothesis. Finally, our results show a wide range of genetic diversity in the Brazilian lima bean accessions maintained by Embrapa. This high variability becomes essential when we consider the source of alleles of interest, which allows us to obtain more productive, resistant and adapted varieties of lima beans through plant breeding.

\section{CONCLUSIONS}

Genetic divergence was found in the lima bean accessions, and the longest distance found was between accessions BF113 and G25633A.

The accessions represent the two centers of domestication: Mesoamerican and Andean. Seed length and width were the characteristics that have contributed the most to genetic divergence between the accessions evaluated.

\section{ACKNOWLEDGEMENTS}

The authors are grateful to Conselho Nacional de Desenvolvimento Cientíico e Tecnológico (CNPq-Brazil) for financial support of this research. Coordenação de Aperfeiçoamento de Pessoal de Nível Superior (CAPES) supported by fellowships and Embrapa Recursos Genéticos e Biotecnologia for support this research.

\section{REFERENCES}

Andueza-Noh, R.H., Martínez-Castillo, J., and Chacón Sánchez, M.I. 2015. Domestication of small-seeded lima bean (Phaseolus lunatus L.) landraces in Mesoamerica: evidence from microsatellite markers. Genetica 142:657669. doi:10.1007/s10709-015-9863-0.

Andueza-Noh, R.H., Serrano-Serrano, M.L., Chacón Sánchez, M.I., Sánchez del Pino, I., Camacho-Pérez, L., Coello-Coello, J., et al. 2013. Multiple domestications of the Mesoamerican gene pool of lima bean (Phaseolus lunatus L.): evidence from chloroplast DNA sequences. Genetic Resources and Crop Evolution 60:1069-1086. doi:10.1007/s10722-012-9904-9.

Baudet, J.C. 1977. The taxonomic status of the cultivated types of lima bean (Phaseolus lunatus L.) Tropical Grain Legume Bulletin 7:29-30.

Cabral, P.D.S., Soares, T.C.B., Gonçalves, L.S.A., Amaral Júnior, A.T., Lima, A.B.P., Rodrigues, R., et al. 2010. Quantification of the diversity among common bean accessions using WardMLM strategy. Pesquisa Agropecuaria Brasileira 45:1124-1132. doi:10.1590/S0100-204X2010001000011.

Castiñeiras, L., Esquivel, M., Rivero, N., and Marino, A. 1991. Variability of the seed of Phaseolus lunatus L. in Cuba. Revista Jardín Botánico Nacional 12:109-114.

Debouck, D.G. 1986. Primary diversification of Phaseolus in the Americas: Three centres? Plant Genetic Resources Newsletter 67:2-8.

Fofana, B., Vekemans, X., Jardin, P., and Baudoin, J.P. 1997. Genetic diversity in Lima bean (Phaseolus lunatus L.) as revealed by RAPD markers. Euphytica 95:157-165. doi:10.1023/A:1002910114869.

Franco, J., Crossa, J., Villasenõr, J., Taba, S., and Eberhart, S.A. 1998. Classifying genetic resources by categorical and continuous variables. Crop Science 38:1688-1696. doi:10.2135/cropsci1998.0011183X003800060045x.

Gonçalves, L.S.A., Rodrigues, R., Amaral Junior, A.T., Karasawa, M., and Sudré, C.P. 2008. Comparison of multivariate statistical algorithms to cluster tomato heirloom accessions. Genetics and Molecular Research 7:1289-1297. doi:10.4238/vol7-4gmr526.

Gonçalves, L.S.A., Rodrigues, R., Amaral Júnior, A.T., Karasawa, M., and Sudré, C.P. 2009. Heirloom tomato gene bank: assessing genetic divergence based on morphological, agronomic and molecular data using a Ward-modified location model. Genetics and Molecular Research 8:364-374. doi:10.4238/vol8-1gmr549.

Gower, J.C. 1971. A general coefficient of similarity and some of its properties. Biometrics 27:857-871. doi:10.2307/2528823.

IBPGR. 1982. Descriptors for Lima bean. International Board for Plant Genetic Resources, Rome, Italy.

Lioi, L. 1994. Morphotype relationships in Lima bean (Phaseolus lunatus L.) deduced from variation of the evolutionary marker phaseolin. Genetic Resources and Crop Evolution 41:81-85. doi:10.1007/BF00053052. 
Lioi, L., and Galasso, I. 2002. Oligonucleotide DNA fingerprinting revealing polymorphism in Phaseolus lunatus L. Genetic Resources and Crop Evolution 49:53-58. doi:10.1023/A:1013809915096.

Lioi, L., Lotti, C., and Galasso, I. 1998. Isozyme diversity, RFLP of the rDNA and phylogenetic affinities among cultivated Lima beans, Phaseolus lunatus L. (Fabaceae). Plant Systematics and Evolution 213:153-164. doi:10.1007/BF00985196.

Maquet, A., Vekemans, X.Z., and Baudoin, J.P. 1999. Phylogenetic study on wild allies of lima bean, Phaseolus lunatus L. (Fabaceae), and implications on its origin. Plant Systematics and Evolution 218:43-54. doi:10.1007/BF01087033.

Maquet, A., Zoro Bi, I., Delvaux, M., Wathelet, B., and Baudoin, J.P. 1997. Genetic structure of a Lima bean base collection using allozyme markers. Theoretical and Applied Genetics 95:980991. doi:10.1007/s001220050651.

Martínez-Castillo, J., Camacho-Perez, L., Coello-Coello, J., and Andueza-Noh, R.H. 2012. Wholesale replacement of Lima bean (Phaseolus lunatus L.) landraces over the last 30 years in northeastern Campeche, Mexico. Genetic Resources and Crop Evolution 59:191-204. doi:10.1007/s10722-011-9675-8.

Martínez-Castillo, J., Camacho-Pérez, L., Villanueva-Viramontes, S., Andueza-Noh, R.H., and Chacón Sanchéz, I. 2014. Genetic structure within the Mesoamerican gene pool of wild Phaseolus lunatus L. (Fabaceae) from Mexico as revealed by microsatellite markers: Implications for conservation and domestication of the species. American Journal of Botany 101:851-864. doi:10.3732/ ajb.1300412.

Martínez-Castillo, J., Colunga-GarcíaMarín, P., and ZizumboVillarreal, D. 2008. Genetic erosion and in situ conservation of Lima bean (Phaseolus lunatus L.) landraces in its Mesoamerican diversity center. Genetic Resources and Crop Evolution 55:1065-1077. doi:10.1007/s10722-008-9314-1.

Mingoti, A.S. 2005. Análise de dados através de métodos de estatística multivariada: uma abordagem aplicada. Editora UFMG, Belo Horizonte, Brasil.
Ortiz, R., Crossa, J., Franco, J., Sevilla, R., and Burgueño, J. 2008. Classification of Peruvian highland maize races using plant traits. Genetic Resources and Crop Evolution 55:151-162. doi:10.1007/s10722-007-9224-7.

Santos, J.O., Araújo, A.S.F., Gomes, R.L.F., Lopes, A.C.A., and Figueiredo, M.V.B. 2008. Rhizobia Phaseolus lunatus Symbiosis: Importance and diversity and tropical soils- a review. Dynamic Soil, Dynamic Plant 2:56-60.

Santos, J.O., Gomes, R.L.F., Lopes, A.C.A., Silva, S.C.C.C., Bastos, E.M., Costa, E.M.R., et al. 2010. Genetic divergence for physical and chemical characters of seeds in lima bean (Phaseolus lunatus L.) Annual Report of the Bean Improvement Cooperative 53:178-179.

Serrano-Serrano, M.L., Andueza-Noh, R.H., Martínez-Castillo, J., Debouck, D.G., and Chacón, M.I. 2012. Evolution and domestication of lima bean (Phaseolus lunatus L.) in Mexico: Evidence from ribosomal DNA. Crop Science 52:1698-1712. doi:10.2135/cropsci2011.12.0642.

Silva, V.B., Gomes, R.L.F., Lopes, A.C.A., Dias, C.T.S., and Silva, R.N.O. 2015. Genetic diversity and promising crosses indication in lima bean (Phaseolus lunatus) accessions. Semina. Ciências Agrárias 36:683-692. doi:10.5433/1679-0359.2015v36n2p683.

Sudré, C.P., Gonçalves, L.S.A., Rodrigues, R., Amaral Júnior, A.T., Riva-Souza, E.M., and Bento, C.S. 2010. Genetic variability in domesticated Capsicum spp. as assessed by morphological and agronomic data in mixed statistical analysis. Genetics and Molecular Research 9:283-294. doi:10.4238/vol9-1 gmr698.

Vargas, E.M., Castro, E., Macaya, G., and Rocha, O.J. 2003. Variation in the size of fruits and seeds in 38 wild populations of Phaseolus lunatus (Fabaceae) from Central Valley of Costa Rica. Revista de Biología Tropical 51:707-724.

Ward Junior, J.H. 1963. Hierarchical grouping to optimize an objective function. Journal of the American Statistical Association 58:236-244. doi:10.1080/01621459.1963.10500845. 